Review Article

\title{
Adapting to extreme environments: Can coral reefs adapt to climate change?
}

\section{James C. Crabbe}

Wolfson College, University of Oxford, Linton Road, Oxford OX2 6UD, UK, and Institute of Biomedical and Environmental Science \& Technology, Department of Life Sciences, University of Bedfordshire, Park Square, Luton, LU1 3JU, UK.

Correspondence: M.J.C.Crabbe (james.crabbe@wolfson.ox.ac.uk and james.crabbe@beds.ac.uk)

\begin{abstract}
Reef-building corals throughout the world have an annual value of tens of billions of dollars, yet they are being degraded at an increasing rate by many anthropogenic and environmental factors. Despite this, some reefs show resilience to such extreme environmental changes. This review shows how techniques in computational modelling, genetics and transcriptomics are being used to unravel the complexity of coral reef ecosystems, to try and understand if they can adapt to new and extreme environments. Considering the ambitious climate targets of the Paris Agreement to limit global warming to $2^{\circ} \mathrm{C}$, with aspirations of even $1.5^{\circ} \mathrm{C}$, questions arise on how to achieve this. Geoengineering may be necessary if other avenues fail, although global governance issues need to play a key role. Development of large and effective coral refugia and marine protected areas is necessary if we are not to lose this vital resource for us all.
\end{abstract}

\section{Introduction}

Scleractinian corals - otherwise known as hard or reef-building corals - arose in the Triassic period c. 237 million years ago [1]. This review will cover warm water corals in the photic zone, down to about $40 \mathrm{~m}$, with a brief mention of mesophotic reefs, which occur c. $40-150 \mathrm{~m}$ deep. The influence of climate change on cold water corals, occurring below 400m, has been covered elsewhere (e.g. [2]).

Coral reefs throughout the world are under severe challenges from a variety of anthropogenic and environmental factors including overfishing, destructive fishing practices, coral bleaching, ocean acidification, sea-level rise, algal blooms, agricultural run-off, coastal and resort development, marine pollution, increasing coral diseases, invasive species, and hurricane/cyclone damage (e.g. $[3,4,5]$ ). Coral bleaching is the detrimental expulsion of algal symbionts from their coral hosts, and predominantly occurs when corals are exposed to thermal stress. Bleached corals are at a greater risk of mortality, although they may partially or fully recover, depending upon the environmental conditions. 
Sea surface temperature (SST) across much of the tropics has increased by $0.4^{\circ}$ to $1^{\circ} \mathrm{C}$ since the mid-1970s, with a parallel increase in the frequency and extent of coral bleaching and [6]. Atmospheric carbon dioxide concentration is expected to exceed 500 parts per million and global temperatures to rise by at least $2^{\circ} \mathrm{C}$ by 2050 to 2100 , values that significantly exceed those of at least the past 420,000 years during which most extant marine organisms evolved. Global warming and ocean acidification will compromise carbonate accretion, with corals becoming increasingly rare on reef systems, and driving reefs toward the tipping point for functional collapse [7]. Scaledup management intervention and decisive action on global emissions are required if the loss of coral-dominated ecosystems is to be avoided.

\section{The Value of Coral reefs}

In 2008, a compilation by Conservation International put the economic value of global coral reefs, mangroves and seagrass beds at just under US \$30 billion per year [8], including tourism, recreation, fisheries, coastal protection, biodiversity, and carbon sequestration. Figure 1 shows the economic benefits from ecosystem services for coral reef ecosystems.

\section{FIGURE 1 HERE}

A more recent estimate shows that the annual expected damages from flooding would double, and costs from frequent storms would triple without reefs [9]. The countries with the most to gain from reef management are Indonesia, the Philippines, Malaysia, Mexico, and Cuba; the annual expected flood savings exceed $\$ 400 \mathrm{M}$ for each of these nations [9].

Global coral reef related tourism is one of the most significant examples of naturebased tourism from a single ecosystem. In 2017 it was found that $30 \%$ of the world's reefs are of value in the tourism sector, with a total value estimated at nearly US\$36 billion, or over $9 \%$ of all coastal tourism value in the world's coral reef countries [10].

\section{Reef degradation and resilience}

The Great Barrier Reef (GBR) is the world's largest coral reef system, composed of over 2,900 individual reefs and 900 islands stretching for over 2,300 kilometres. A 27-year time series to 2012 on GBR reef condition showed a major decline in coral cover from $28.0 \%$ to $13.8 \%\left(0.53 \% \mathrm{y}^{-1}\right)$, with tropical cyclones, coral predation by crown-of-thorns starfish (COTS), and coral bleaching accounting for $48 \%, 42 \%$, and $10 \%$ of the respective estimated losses [11]. At that time, the relatively pristine northern region showed no overall decline. Since then, the GBR, in common with reefs globally [12] has seen unprecedented bleaching events [13], and continues to suffer from repeated impacts of cyclones, coral bleaching, and COTS outbreaks. This raises the question of the ecosystem's systemic resilience and its ability to rebound after large-scale population loss. 
But what is reef resilience, and what is its relation to reef community stability? One can define community stability as the ability to maintain a given state regardless of perturbation, invasion, or extinction [14]. Stability is made up of two components: resistance - the degree to which a community changes in response to a disturbance, and recovery or "resilience"-the rate of return to pre-disturbance conditions [14, 15]. Species richness (the number of species within an area) is thought to influence community stability, although for communities in biodiverse regions, such as the Western Pacific, corals may not be more resistant and resilient to natural and anthropogenic disturbances [15].

Around 100 reefs of the GBR, or around 3\%, have the ideal properties to facilitate recovery of disturbed areas, thereby imparting a level of systemic resilience and aiding its continued recovery [16]. Figure 2 identifies robust sources on the GBR. These reefs (1) are highly connected by ocean currents to the wider reef network, (2) have a relatively low risk of exposure to disturbances so that they are likely to provide replenishment when other reefs are depleted, and (3) have an ability to promote recovery of desirable species but are unlikely to either experience or spread COTS outbreaks. The replenishment potential of these 'robust source reefs' arises from the interaction between oceanographic conditions and geographic location, a process that is likely to be repeated in other reef systems [16]. The full impact of the 2016 GBR bleaching event may not be realized until dead corals erode during the next decade. However, short-term observations suggest that the recovery processes, and the ultimate scale of impact, are affected by functional changes in reef communities [17].

\section{FIGURE 2 HERE}

Of all the world's reefs, Caribbean reefs in particular have transitioned to coraldepleted systems and exhibited less coral resilience. Why? This is not necessarily a region-wide issue, for example in the Florida Keys bare rock is more plentiful than algae, which predominate elsewhere in the Caribbean. On its own, coral recruitment does not translate to reef recovery in the Keys [17a], as recruits show poor survival, for complex, and indeed controversial, reasons also involving bioerosion and sediment transport [17b]. Coral loss results in more abundant seaweeds that release dissolved organic carbon (DOC), which is consumed by sponges, which in turn return carbon to the reef but also release nutrients that further enhance seaweed growth [18]. This synthesis has implications for the conservation of Caribbean coral reefs that are related to fisheries and watershed management.

Plastic waste can promote microbial colonization by pathogens implicated in outbreaks of disease in the ocean. The likelihood of disease increased from $4 \%$ to $89 \%$ when corals were in contact with plastic in 124,000 reef-building corals from 159 reefs in the Asia-Pacific region [19]. Over 11 billion plastic items were estimated to be entangled on coral reefs across the Asia-Pacific, a number projected to increase $40 \%$ by 2025 [19]. Plastic waste management in the oceans is critical for reducing diseases that threaten ecosystem health and human livelihoods.

Sea-level rise (SLR) is predicted to elevate water depths above coral reefs and to increase coastal wave exposure as ecological degradation limits vertical reef growth. Threshold coral cover levels that will be necessary to prevent submergence are well above those observed on most reefs [20]. Urgent action is thus needed to mitigate 
climate, sea-level and future ecological changes in order to limit the magnitude of future reef submergence.

Ocean acidification is a pervasive threat to coral reef ecosystems, owing to alterations in oceanic $\mathrm{CaCO}_{3}$ saturation, influencing $\mathrm{pH}$ and aragonite saturation [7, 21]. Low aragonite saturation can reduce coral cover, allowing increases in macroalgal growth and shfts in community assemblages and biodiversity [22, 23]. Photophysiological dysfunction of the algal symbionts can also be caused by elevated $\mathrm{CO}_{2}$ partial pressure $\left(\mathrm{pCO}_{2}\right)[24]$.

\section{Monitoring and data analysis of coral reefs and climate change}

NOAA's (National Oceanic and Atmospheric Administration in Washington, USA) Coral Reef Watch (CRW) developed and maintains a suite of operational satellite sea surface temperature (SST)-based products that provide coral bleaching 'nowcasts' and alerts $[25,26]$. HotSpots are positive SST anomalies beyond coral's tolerance level that reflect instantaneous thermal stress, and Degree Heating Weeks (DHWs) provide a measure of sustained thermal stress during a 12-week period. Figure 3 summarizes key meteorological processes and coral requirements controlling calcification, photosynthesis and survival.

\section{FIGURE 3 HERE}

In 2005, NOAA warned coral reef managers and scientists of anomalously warm conditions as they developed and spread across the greater Caribbean region. Thermal stress during the 2005 event exceeded any observed from the Caribbean in the prior 20 years, and regionally-averaged temperatures were the warmest in over 150 years. Figure 4 shows the thermal stress and bleaching during the 2005 Caribbean bleaching event. Comparison of satellite data against field surveys demonstrated a significant predictive relationship between accumulated heat stress and bleaching intensity - over $80 \%$ of corals bleached and over $40 \%$ died at many sites [27].

\section{FIGURE 4 HERE}

Modelling of historical SST patterns and associated anomalies (1982-2012) indicated that the northern Red Sea has not experienced mass bleaching despite intensive Degree Heating Weeks (DHW) of $>15^{\circ} \mathrm{C}$-weeks [27]. The northern Red Sea may harbour reef-building corals that live well below their bleaching thresholds and may represent a thermal refuge of global importance [28]. Reefs with greater highfrequency temperature variability may represent opportunities to conserve coral ecosystems against the major threat posed by warming ocean temperatures [29]. However, one should be cautious. The increased salinity prevalent in the Red Sea and the Persian Gulf may provide an additional bleaching resilience factor, so that these corals may not be so suitable for seeding in areas where the salinity is less extreme.

Modelling can also help in identifying 'oases' within coral reef regions [30, 31]. Using coral cover and coral calcification capacity (CCC) 38 out of 123 sites in the Pacific 
and Western Atlantic were identified as 'oases' to help in conservation planning [30]. Coral calcification is crucial [31], and is driven by temperature in reefs off Bermuda [33].

Metapopulation models in the Persian Gulf suggest that increased frequency of disturbance causes progressive reduction in coral size, cover, and population fecundity [34]. Also, the greater the frequency of disturbance, the more larval connectivity is required to maintain the metapopulation. Oceanographic modelling of larval retention and connectivity suggests that correlated disturbances across populations will lead to winnowing of species due to colony, tissue, and fertility losses, with resultant insufficient dispersal potential to make up for losses, especially as disturbances increase under climate change [34].

Reef habitat complexity and structural components are important to different taxa of macrofauna, total species richness, and individual coral and fish species [34]. Flattening of Caribbean coral reefs will result in substantial species losses, and their loss may have profound impacts reef population richness and resilience, and may affect essential ecosystem processes and services [35].

\section{On the cusp of ecological diversity, dynamics and physiology; genomics and transcriptomics}

Climate change influences all levels of coral biology, from genetics and epigenetics through physiology and microbial ecology to population dynamics and the potential for reef recovery from a systems perspective. The advent of next-generation sequencing tools has made it possible to conduct fine-scale surveys of population differentiation and genome-wide scans for signatures of selection. Such surveys are of particular importance in sharply declining coral species, since knowledge of population boundaries and signs of local adaptation can inform restoration and conservation efforts [36]. Coral genomes can be surprisingly disparate, as shown by the genomes of Stylophora pistillata and Acropora digitifera. Both corals diverged as the identity of ortholog groups expanded, and there were uneven expansions in genes associated with innate immunity and stress response [37]. Figure 5 shows an overview of processes associated with gene expansions in $S$. pistillata and $A$. digitifera.

\section{FIGURE 5 HERE}

Genome-wide surveys of single-nucleotide polymorphisms in the threatened Caribbean elkhorn coral, Acropora palmata, revealed fine-scale population structure and suggested the major barrier to gene flow that separates the eastern and western Caribbean populations between the Bahamas and Puerto Rico [36].

Reef-building corals depend on symbiotic mutualisms with photosynthetic dinoflagellates in the genus Symbiodinium. This large microalgal group comprises many highly divergent lineages ("Clades A-I") and hundreds of undescribed species. Today's reef-building corals exploded in diversity around 160 million years ago [38], and it may be that the partnership with Symbiodiniaceae was one of the major reasons for the success of modern corals. There is genetic evidence [38] that the 
family comprises at least 15 genera, including hundreds and possibly thousands of species worldwide, each with different characteristics that influence the effect of the environment on the corals.

Genetic research is now focusing on both clades and species [38, 39], for example describing transcriptional variation among strains involving fatty acid metabolism and biosynthesis pathways. Such differences among individuals are potentially a major source of physiological variation, contributing to the functional diversity of coral holobionts composed of unique host-symbiont genotype pairings [38].

Many coral genomes and transcriptomes are being sequenced, and being made available for further research [e.g. 40, 41]. For example the Montastrea cavernosa genome is being updated at: https://matzlab.weebly.com/data--code.html $<$ https://matzlab.weebly.com/data--code.html>

There are also transcriptomes available at this website for Acropora millepora, Montipora aequituberculata, Acropora hyacinthus , Porites astreoides, Acropora tenuis and Acropora cervicornis. All sequences are fully referenced on the website.

Comparative genomics shows the evolutionary success of scleractinian corals, as well as their vulnerability $[42,43]$. Population genomic surveys suggest that climateassociated genetic variation occurs widely across species, but whether it is sufficient to allow population persistence via evolutionary adaptation has seldom been quantified. Genetic variation at predicted warm-adapted loci and simulated future evolution and persistence in a high-latitude population of corals from Rarotonga, Cook Islands, showed rapid evolution of heat tolerance resulting in population persistence under mild warming scenarios consistent with low $\mathrm{CO}_{2}$ emission plans, RCPs (Representative Concentration Pathways) RCP2.6 and RCP4.5. RCPs are named after a possible range of radiative forcing values in the year 2100 relative to pre-industrial values. Under more severe scenarios, RCP6.0 and RCP8.5, adaptation was not rapid enough to prevent extinction [44]. Incorporation of genomic data into models of species response to climate change offers a promising method for estimating future adaptive processes [45]. This has been done with Orbicella faveolata in the wider Caribbean, which shows that Eastern and western populations appear segregated with a genetic break around the Mona Passage, with a strong genetic break within the Mesoamerican Barrier Reef System associated with complex oceanographic patterns that promote larval retention in southern Belize [46]. Continuing interdisciplinary research on the cusp of ecological diversity, dynamics and physiology using genomics and transcriptomics techniques may help us to learn more about a systems approach to coral reefs and their role in a wider ecosystems approach, involving seagrass beds, mangroves and forests.

\section{Can we learn from the adaptation and evolution of other ecosystems?}

Mesophotic coral reefs at depths of 30 to 150 meters have been hypothesized to provide refuge from natural and anthropogenic impacts, a promise for the survival of shallow reefs [e.g. 47]. The potential role of mesophotic or perhaps even submesophotic - rariphotic- reefs [48] as universal refuges has been highlighted in reef 
conservation research. This hypothesis rests on two assumptions: (i) that there is overlap in species composition and connectivity between shallow and deep populations and (ii) that deep reefs are less susceptible to anthropogenic and natural impacts than their shallower counterparts. However, these assumptions have been criticised [49], with evidence that mesophotic reefs are distinct, impacted, and in as much need of protection as shallow coral reefs. Further research is necessary on these deeper reefs to establish whether they could act as refugia for their shallower counterparts.

What can we learn from other extreme environments on the planet? The QinghaiTibet Plateau (QTP) is not only the highest and largest young plateau in the world, but also has the most variety of extreme environments, including rapid fluctuations in temperature, low oxygen concentration, low pressure, strong ultraviolet (UV) radiation, and severe winds. The QTP is also one of the global biodiversity hotspots with many unique environments, including snowy mountains, saline lakes, and arid deserts [50]. These environments provide an ideal natural laboratory for studies on adaptive evolution. Organisms that live in the QTP must have undergone a series of significant adaptive evolutionary genetic changes to produce a wide range of ecologically adaptive characters [51, 52]. Cyanobacteria can exist symbiotically in corals [53], and genome and transcriptome sequencing of cyanobacteria Trichormus sp. NMC-1 in the QTP suggested that CheY-like genes, extracellular polysaccharide and mycosporine-like amino acids might play major roles in adaptation to harsh environments [54]. This is important as mycosporine-like amino acids also play a major photoprotective role in UV absorption in corals, as in other marine organisms [e.g. 55]. Future coral reef research needs to learn from other organisms and ecosystems about adaptation and evolution in extreme environments.

\section{Geoengineering}

Considering the ambitious climate targets of the Paris Agreement to limit global warming to $2^{\circ} \mathrm{C}$, with aspirations of even $1.5^{\circ} \mathrm{C}$, questions arise on how to achieve this. Climate geoengineering has been proposed as a potential tool to minimize global harm from anthropogenic climate change. Generally, geoengineering techniques can be grouped in two categories: Carbon Dioxide Removal (CDR) and Solar Radiation Management (SRM). CDR techniques aim to remove carbon dioxide from the atmosphere, directly counteracting the increased greenhouse effect and ocean acidification. These techniques (e.g. afforestation, biochar, bio energy with carbon capture and sequestration, ambient air capture, ocean fertilisation, enhanced weathering, ocean alkalinity enhancement) should be implemented on a global scale to make a significant impact on carbon dioxide levels in the atmosphere. SRM techniques aim to reflect a small proportion of the Sun's energy back to space, counteracting an increasing level of greenhouse gases in the atmosphere which absorb energy and raise temperature. Some SRM techniques are albedo enhancement, and the use of either space reflectors or stratospheric aerosols through stratospheric sulphate injection (SSI), or Marine Cloud Brightening (MCB) with sea spray in the Troposphere [e.g. 56, 57]. Targeted geoengineering could also mitigate against sea level rise [58]. 
Modelling stratospheric aerosol geoengineering from 2020-2069 with daily injections of $\mathrm{SO}_{2}$ at a rate of $5 \mathrm{Tg} \mathrm{SO}_{2}$ per year, shows that coral bleaching in the Caribbean would not occur, except for some small regions near the southern coastline or east of Florida, while under the RCP4.5 scenario, coral bleaching will occur in most parts of the northern Caribbean Sea [58]. Figure 6 shows the projected coral bleaching area under stratospheric aerosol geoengineering and RCP4.5 scenarios in 2030, 2050 and 2069. Any changes in downward solar irradiation, sea level rise and the change of sea temperature variation in the Caribbean Sea caused by geoengineering implementation would have very little impact on coral growth [58]. For the impact related to severe Category 5 hurricanes, although geoengineering could prolong the return period of hurricanes during 2020-2069, if compared with the RCP4.5 scenario, it may not be enough for corals to recover after hurricane impacts [59].

\section{FIGURE 6 HERE}

Geoengineering is fraught with potential difficulties. For example, what would happen if SRM aerosol injection was stopped? Modelling studies show that within two decades the climate would revert to the path of RCP8.5, questioning the sustainable nature of such climate geoengineering [60]. Mitigation during any such form of climate geoengineering would be needed to limit termination risks. While forest management and afforestation are natural methods of CDR [e.g. 61, 62], in North American forests future (2080s) biomass will only sequester at most $22 \%$ more carbon than the current level [62].

Another major issue is governance. The lack of global governance is exemplified by the problems experienced before and after the Paris Agreement. How easy would it be to get agreement on geoengineering options? And how would implementation be monitored? Important and difficult questions arise from interactions between climate engineering, climate mitigation, and food production and consumption. Geoengineering intersects with other sectors and trends in all geographical regions and at all levels and scales of governance [63]. Geoengineering patents could also be an issue [64]. Nonetheless, it is important to continue to fund and carry out geoengineering research as such an approach may become necessary to preserve our vulnerable ecosystems.

\section{Protecting coral reefs: challenges and possibilities}

Against a backdrop of natural and anthropogenic insults [65], an important question is: how can management practices maintain sustainable coral reef ecosystems? Integrated Coastal Zone Management (ICZM) is a complex worldwide governance issue requiring an integrated and coordinated approach. It involves many relevant stakeholders and policy initiatives need to be developed over long time scales. Ideally, marine ecosystems (i.e., corals, seagrass beds) should be closely linked to terrestrial ecosystems such as mangroves and coastal forests. Some corals can acclimatize to increasing heat regimes [66]. One challenge is the replacement of scleractinian corals by macroalgae - a macroalgal regime shift - which reduces the ecological, social, and economic value of affected reefs. This is happening globally, not just in the Caribbean [67,68], and leads to two bottlenecks to coral recovery; inhibition of coral recruitment and recruit survival by macroalgae, and reduced 
juvenile coral persistence in patches of loose rubble [68]. Another problem in the corals themselves is that ocean warming destabilizes the coral symbiosis with the dinoflagellate algae, Symbiodinium, producing disparity in benefits and costs to both partners producing symbiont parasitism in the coral [69]. The symbiont algae may also modulate the immunological function of the host [70].

Refugia can facilitate the persistence of biodiversity under changing environmental conditions, such as anthropogenic climate change, and therefore may constitute the best chance of survival for many coral species in the wild. Six criteria have been proposed that determine the capacity of refugia to facilitate species persistence, including long-term buffering, protection from multiple climatic stressors, accessibility, microclimatic heterogeneity, size, and low exposure to non-climate disturbances [71]. Stability of the substratum is also important [72]. Any effective high-capacity coral reef refugium should be characterized by long-term buffering of environmental conditions. This could become increasingly more difficult as marine heatwaves - periods of extreme warm SSTs that persist for days to months over large areas - are set to increase [73] Seagrass habitats may not serve as refugia against climate change if the magnitude of future temperature and $\mathrm{pH}$ changes is equivalent to neighbouring reef habitats [74]. Rat eradication on oceanic islands should be a high conservation priority as it is likely to benefit terrestrial ecosystems and enhance coral reef productivity and functioning by restoring seabird-derived nutrient subsidies from large areas of ocean [75].

Marine Protected Areas (MPAs) are one of the few management tools that governments and local communities can use to combat large scale environmental impacts [e.g. 76]. However, ideally they need to be no-take, well enforced, old ( $>10$ years), large (>100 km2) and isolated by deep water or sand [77]. There should be well designed networks of MPAs based on conservation priorities [e.g. 78], that are planned effectively in conjunction with other management enforcement strategies, such as fisheries regulations and reductions of nutrients and other forms of landbased pollution $[79,80]$.

2018 is the third International Year of the Reef (IYOR 2018), and many initiatives have been carried out worldwide - see https://www.iyor2018.org/ for the latest details. As an example, Hawai'i became the first US state to ban sunscreens harmful to coral reefs, as a result of research in the area [81]. Research in microplastics and corals [82] is also informing policy for the future.

\section{Conclusion}

Although widespread loss and degradation of coral reefs due to climate change is expected over the coming decades, strategic management of local and global threats, along with emerging molecular and other technologies, provide opportunities for us to improve the long-term conservation and persistence of coral reefs. Success in saving coral reefs, however, ultimately depends on the global community meeting or exceeding the science-based targets agreed to in Paris in December 2015. 


\section{Summary}

- Coral reefs throughout the world are under severe challenges from a variety of anthropogenic and environmental factors including overfishing, destructive fishing practices, coral bleaching, ocean acidification, sea-level rise, algal blooms, agricultural run-off, coastal and resort development, marine pollution, increasing coral diseases, invasive species, and hurricane/cyclone damage.

- $30 \%$ of the world's reefs are of value in the tourism sector, with a total value estimated at nearly US\$36 billion.

- Comparison of satellite data from NOAA against field surveys demonstrated a significant predictive relationship between accumulated heat stress and bleaching intensity - in 2005 over $80 \%$ of corals bleached and over $40 \%$ died at many sites in the Caribbean.

- Coral reef research needs to learn from other organisms and ecosystems, for example the Qinghai-Tibet Plateau, about adaptation and evolution in extreme environments.

- Modelling of solar radiation management shows it would prevent coral bleaching in the Caribbean. It is important to continue to fund and carry out geoengineering research as such an approach may become necessary to preserve our vulnerable ecosystems.

- Marine Protected Areas (MPAs) are one of the few management tools that governments and local communities can use to combat large scale environmental impacts. They need to be no-take, well enforced, old ( $>10$ years), large (>100 km2) and isolated by deep water or sand.

- Success in saving coral reefs ultimately depends on the global community meeting or exceeding the science-based targets agreed to in Paris in December 2015.

\section{Competing Interests}

The Author declares that there are no competing interests associated with the manuscript.

\section{References}

1 Stanley, G.D. Jr. (2003) The evolution of modern corals and their early history. Earth Science Review 60, 195-225.

2 Roberts, J.M., Murray, F., Anagnostou, E., Hennige, S., Gori, A., Henry, L-A., Fox, A., Kamenos, N. and Foster, G.L. (2016) Cold-Water Corals in an Era of Rapid Global Change: Are these the Deep Ocean's Most Vulnerable Ecosystems? In: The 
Cnidaria, past present and future: The world of medusa and her sisters (Goffredo, S. and Dubinsky, Z., eds) pp. 593-606, Springer Verlag, Switzerland.

3 Gardner, T.A., Côté, I.M., Gill, J.A., Grant, A. and Watkinson A.R. (2003) Longterm region-wide declines in Caribbean corals. Science 301, 958-960.

4 Bellwood, D.R., Hughes, T.P., Folke, C. and Nyström, M. (2004) Confronting the coral reef crisis. Nature 429, 827-833.

5 Crabbe, M.J.C. (2016) The impact of climate change and the environment on coral growth. In: The Cnidaria, past present and future: The world of medusa and her sisters (Goffredo, S. and Dubinsky, Z., eds) pp. 577-592, Springer Verlag, Switzerland.

6 Cantin, N.E., Cohen, A.L., Karnauskas, K.B., Tarrant, A.M. and McCorkle, D.C. (2010) Ocean Warming Slows Coral Growth in the Central Red Sea. Science 329, 322-325.

7 Hoegh-Guldberg, O., Mumby, P.J., Hooten, A.J. et al. (2007) Coral Reefs under Rapid Climate Change and Ocean Acidification. Science 318, 1737-1742.

8 Conservation International (2008) Economic Values of Coral Reefs, Mangroves, and Seagrasses: A Global Compilation. 37pp., Arlington, USA. https://www.icriforum.org/sites/default/files/Economic_values_global\%20compilation. pdf

9 Beck, M.W., Losada, I.J., Menéndez, P., Reguero, B.G., Díaz-Simal, P. and Fernández, F. (2018) The global flood protection savings provided by coral reefs. Nature Communications 9, 2186. DOI: 10.1038/s41467-018-04568-z

10 Spalding, M., Burke, L., Wood, S.A., Ashpole, J., Hutchison, J. and Ermgassen, P. z. (2017) Mapping the global value and distribution of coral reef tourism. Marine Policy 82, 104-113. See also: http://maps.oceanwealth.org/\#

11 De'ath, G., Fabricius, K.E., Sweatman, H. and Puotinen, M. (2012) The 27-year decline of coral cover on the Great Barrier Reef and its causes. Proceedings of the National Academy of Sciences USA 109, 17995-17999.

12 Heron, S. F., Maynard, J.A., van Hooidonk, R. and Eakin, C.M. (2016) Warming Trends and Bleaching Stress of the World's Coral Reefs 1985-2012. Sci. Rep.6, 38402; doi: 10.1038/srep38402.

13 Hughes, T.P., Kerry, J.T., Álvarez-Noriega, M. et al. (2017) Global warming and recurrent mass bleaching of corals. Nature 543, 373-377.

14 McCann, K.S. (2000) The diversity-stability debate. Nature 405, 228-233.

15 Zhang, S.Y., Speare, K.E., Long, Z.T. et al. (2014), Is coral richness related to community resistance to and recovery from disturbance? PeerJ 2, e308; DOI 10.7717/peerj.308 
16 Hock, K., Wolff, N.H., Ortiz, J.C., Condie, S.A., Anthony, K.R.N., Blackwell, P.G. et al. (2017) Connectivity and systemic resilience of the Great Barrier Reef. PLoS Biol 15, e2003355. https://doi.org/10.1371/journal.pbio.2003355

17 Stuart-Smith, R.D., Brown, C.J., Ceccarelli, D.M. and Edgar, G.J. (2018) Ecosystem restructuring along the Great Barrier Reef following mass coral bleaching. Nature 560, 92-96. DOI https://doi.org/10.1038/s41586-018-0359-9.

17a van Woesik, R., Scott, W.J. and Aronson, R.B. (2014) Lost opportunities: coral recruitment does not translate to reef recovery in the Florida Keys. Marine Pollution Bulletin 88, 110-117. doi: 10.1016/j.marpolbul.2014.09.017.

17b Kuffner, I.B. and Toth, L.T. (2016) A geological perspective on the degradation and conservation of western Atlantic coral reefs. Conservation Biology 30, 706-715.

18 Pawlik, J.R., Burkepile, D.E. and Thurber, R.V. (2016) A Vicious Circle? Altered Carbon and Nutrient Cycling May Explain the Low Resilience of Caribbean Coral Reefs. BioScience 66, 470-476.

19 Lamb, J.B., Willis, B.L., Fiorenza, E.A., Couch, C.S., Howard, R. and Rader, D.N. (2018) Plastic waste associated with disease on coral reefs. Science, 359, 460-462 DOI: $10.1126 /$ science.aar3320

20 Perry, C.T., Alvarez-Filip, L., Graham, N.A.J, et al. (2018) Loss of coral reef growth capacity to track future increases in sea level. Nature 558, 396-400.

21Crabbe, M.J.C., Walker, E.L.L. and Stephenson, D.B. (2008) The impact of weather and climate extremes on coral growth. In: Climate Extremes and Society (Diaz, H.F. and Murnane, R.J., eds) pp. 165-188, Cambridge University Press, Cambridge, UK.

22 Crook, E.D., Kroeker, K.J., Potts, D.C., Rebolledo-Vieyra, M., HernandezTerrones, L.M. and Paytan, A. (2016) Recruitment and Succession in a Tropical Benthic Community in Response to In-Situ Ocean Acidification. PLoS ONE 11, e0146707.

doi:10.1371/journal.pone.0146707

23 Agostini, S., Harvey, B.P., Wada, S., Kon, K. et al. (2018) Ocean acidification drives community shifts towards simplified non-calcified habitats in a subtropical-temperate transition zone. Scientific Reports $\mathbf{8 , 1 1 3 5 4}$ | DOI:10.1038/s41598-018-29251-7.

24 Bedwell-Ivers, H. E., Koch, M. S., Peach, K. E., Joles, L., Dutra, E., and Manfrino, C. (2017) The role of in hospite zooxanthellae photophysiology and reef chemistry on elevated pCO2 effects in two branching Caribbean corals: Acropora cervicornis and Porites divaricata. ICES Journal of Marine Science 74, 1103-1112. doi:10.1093/icesjms/fsw026.

25 Liu, G., Strong, A.E., Skirving, W.J. and Arzayus LF (2006) Overview of NOAA Coral Reef Watch Program's near-real-time satellite global coral bleaching 
monitoring activities. Proceedings of the 10th International Coral Reef Symposium: Okinawa. pp 1783-1793.

26 Beyer, H.L., Kennedy, E.V., Beger, M. et al. (2018) Risk-sensitive planning for conserving coral reefs under rapid climate change. Conservation Letters. 2018; e12587. https://doi.org/10.1111/conl.12587

27 Eakin, C.M., Morgan, J.A., Heron, S.F., Smith, T.B., Liu, G. et al. (2010) Caribbean Corals in Crisis: Record Thermal Stress, Bleaching, and Mortality in 2005. PLOS ONE 5, e13969. doi:10.1371/journal.pone.0013969

28 Osman, E.O., Smith, D.J., Ziegler, M., Kürten, B., Conrad, C. et al. (2018) Thermal refugia against coral bleaching throughout the northern Red Sea. Glob Chang Biol. 24,:e474-e484. doi: 10.1111/gcb.13895. Epub 2017 Oct 17.

29 Safaie, A., Silbiger, N.J., McClanahan, T.R., Pawlak, G. et al. (2018) High frequency temperature variability reduces the risk of coral bleaching. Nature Communications 9,1671 DOI: 10.1038/s41467-018-04074-2

30 Guest, J.R., Edmunds, P.J., Gates, R.D., Kuffner, I.B. et al. (2018) A framework for identifying and characterising coral reef "oases" against a backdrop of degradation. Journal of Applied Ecology 2018, 1-11. DOI: 10.1111/1365-2664.13179

31 Webster, M. S., Madhavi, A. C., Darling, E. S., Armstrong, J., Pinsky, M.

L., Knowlton, N., \& Schindler, D. E. (2017). Who should pick the winners

of climate change? Trends in Ecology and Evolution, 32, 167-173. https://doi.org/10.1016/j.tree.2016.12.007

32 Franco, C., Hepburn, L.A., Smith, D.J. et al. (2016) A Bayesian Belief Network to assess rate of changes in coral reef Ecosystems. Environmental Modelling \& Software 80, 132-142.

33 Courtney, T.A., Lebrato, M., Bates, N.R., Collins, A. et al. (2017) Environmental controls on modern scleractinian coral and reef-scale calcification. Science Advances 3, e1701356.

34 Riegl, B., Cavalcante, G., Bauman, A.G., Feary, D.A. et al. (2017) Demographic Mechanisms of Reef Coral Species Winnowing from Communities under Increased Environmental Stress. Frontiers in Marine Science 4, 344. doi: 10.3389/fmars.2017.00344

35 Newman, S.P., Meesters, E.H., Dryden, C.S., Williams, S.M. et al. (2015) Reef flattening effects on total richness and species responses in the Caribbean. Journal of Animal Ecology 84, 1678-1689. doi: 10.1111/1365-2656.12429

36 Devlin-Durante, M.K. and Baums, I.B. (2017) Genome-wide survey of singlenucleotide polymorphisms reveals fine-scale population structure and signs of selection in the threatened Caribbean elkhorn coral, Acropora palmata. PeerJ 5, e4077. doi:10.7717/peerj.4077. 
37 Voolstra, C.R., Li, Y., Baumgarten, S., Zoccola, D. et al. (2017) Comparative analysis of the genomes of Stylophora pistillata and Acropora digitifera provides evidence for extensive differences between species of corals. Scientific Reports 2017. DOI: $10.1038 / \mathrm{s} 41598-017-17484-x$

38 LaJeunesse, T.C., Parkinson, J.E., Gabrielson, P.W. Jeong, H.J. et al. (2018) Systematic Revision of Symbiodiniaceae Highlights the Antiquity and Diversity of Coral Endosymbionts. Current Biology 2018, DOI: 10.1016/j.cub.2018.07.008

39 Barfield, S. J., Aglyamova, G. V., Bay, L. K. and Matz, M. V. (2018) Contrasting effects of Symbiodinium identity on coral host transcriptional profiles across latitudes. Molecular Ecololgy 2018 doi:10.1111/mec.14774

40 Cleves, P.A., Strader, M.E., Bay, L.K., Pringle, J.R. and Matz, M. V. (2018) CRISPR/Cas9-mediated genome editing in a reef-building coral. Proc Natl Acad Sci U S A 115, 5235-5240. doi: 10.1073/pnas.1722151115.

41 Matz, M. V., Treml, E.A., Aglyamova, G. V., and Bay L.K. (2018) Potential and limits for rapid genetic adaptation to warming in a Great Barrier Reef coral. PLOS Genet 14, e1007220.

42 Bhattacharya, D., Agrawal,S., Aranda, M., Baumgarten, S. et al. (2016) Comparative genomics explains the evolutionary success of reef-forming corals eLife 5, e13288. DOI: $10.7554 /$ LLife. 13288

43 Renema, W., Pandolfi, J.M., Kiessling, W., Bosellini, F.R. et al. (2016) Are coral reefs victims of their own past success? Science Advances 2, e1500850 (2016).

44 Bay, R.A., Rose, N.H., Logan, C.A. and Palumbi, S.R. (2017) Genomic models predict successful coral adaptation if future ocean warming rates are reduced. Science Advances 3, e1701413.

45 Marie E. Strader, M.E., Aglyamova, G.V. and Matz, M.V. (2018) Molecular characterization of larval development from fertilization to metamorphosis in a reefbuilding coral. BMC Genomics 19, 17. DOI 10.1186/s12864-017-4392-0.

46 Rippe, J.P., Matz, M.V., Green, E.A., Medina, M. et al. (2017) Population structure and connectivity of the mountainous star coral, Orbicella faveolata, throughout the wider Caribbean region. Ecology and Evolution 7, 9234-9246.

47 Muir, P.R., Marshall, P.A., Abdulla, A. and Aguirr, J.D. (2017) Species identity and depth predict bleaching severity in reef-building corals: shall the deep inherit the reef? Proceedings of the Royal Society B 284 (1864), Pii 20171551. doi: 10.1098/rspb.2017.

48 Baldwin, C.C., Tornabene, L. and Roberetson, D.R. (2018) Below the Mesophotic. Scientific Reports 8, 4920 | DOI:10.1038/s41598-018-23067-1. 
49 Rocha, L.A., Pinheiro, H.T., Shepherd, B., Papastamatiou, Y.P. et al. (2018) Mesophotic coral ecosystems are threatened and ecologically distinct from shallow water reefs. Science 361, 281 DOI: 10.1126/science.aaq1614.

50 Favre, A., Päcker, M., Pauls, S.U., Jähnig, S.C. et al. (2015) The role of the uplift of the Qinghai-Tibetan Plateau for the evolution of Tibetan biota. Biological Reviews 90, 236-253. 236 doi: 10.1111/brv.12107

51 Wan, D.-S., Feng, J.-J., Jiang, D.-C., Mao, K.-S. et al. (2016) The Quaternary evolutionary history, potential distribution dynamics, and conservation implications for a Qinghai-Tibet Plateau endemic herbaceous perennial, Anisodus tanguticus (Solanaceae). Ecology and Evolution 6, 1977-1995. doi: 10.1002/ece3.2019

52 Zeng, L., Gu, Z., Xu, M., Zhao, N. et al. (2017) Discovery of a high-altitude ecotype and ancient lineage of Arabidopsis thaliana from Tibet. Science Bulletin 62, 1628-1630.

53 Lesser, M.P., Mazel, C.H., Gorbunov, M.Y. and Falkowski, P.G. (2004) Discovery of symbiotic nitrogen-fixing cyanobacteria in corals. Science. 305, 9971000.

54 Qiao, Q., Huang, Y., Qi, J., Qu, M., Jiang, C. et al (2016) The genome and transcriptome of Trichormu sp. NMC-1: insights into adaptation to extreme environments on the Qinghai-Tibet Plateau. Scientific Reports 6, 29404. DOI: $10.1038 /$ srep29404.

55 Rosic, N.N. and Dove, S. (2011) Mycosporine-Like Amino Acids from Coral Dinoflagellates. Applied and Environmental Microbiology 77, 8478-8486.

56 Lenton, T.M. and Vaughan, N.E. (2009) The radiative forcing potential of different climate geoengineering options. Atmospheric Chemistry and Physics 9, 5539-5561.

57 Kwiatkowski, L., Cox, P., Halloran, P.R., Mumby, P.J. and Wiltshire, A.J. (2015) Coral bleaching under unconventional scenarios of climate warming and ocean acidification. Nature Climate Change 5, 777-781. DOI: 10.1038/nclimate2655.

58 Moore, J. C., Gladstone, R., Zwinger, T., and Wolovick, M. (2018) Geoengineer polar glaciers to slow sea-level rise, Nature 555, 303-305. https://doi.org/10.1038/d41586-018-03036-4, 2018.

59 Zhang, Z., Jones, A. and Crabbe, M.J.C. (2018) Impacts of Stratospheric Aerosol Geoengineering Strategy on Caribbean Coral Reefs. International Journal of Climate Change Strategies and Management 10, 523-532. https://doi.org/10.1108/IJCCSM05-2017-0104.

60 Muri, H., Tjputra, J., Otterå, O.H., Adakudlu, M., Lauvset, S. et al. (2018) Climate Response to Aerosol Geoengineering: A Multimethod Comparison. Journal of Climate 31, 6319-6340.

61 Li, H., Xu, F., Crabbe, M.J.C., Wang, W. et al. (2017) Seasonal variations in carbon, nitrogen and phosphorus concentrations and $\mathrm{C}: \mathrm{N}: \mathrm{P}$ stoichiometry in different 
organs of a Larix principis-rupprechtii Mayr. plantation in the Qinling Mountains, China. PLoS ONE 12, e0185163. https://doi.org/10.1371/journal.pone.0185163.

62 Kai Zhu, K., Zhang, J., Niu, S., Chu, C. and Luo, Y. (2018) Limits to growth of forest biomass carbon sink under climate change. Nature Communications 9, 2709. DOI: $10.1038 / \mathrm{s} 41467-018-05132-5$.

63 Preston, C.J. (ed.) (2016) Climate Justice and Geoengineering: Ethics and Policy in the Atmospheric Anthropocene. London-New York, Rowman \& Littlefield International. 209 pp.

64 Rimmer, M. (2018) Intellectual ventures: Patent law, climate change, and geoengineering. In: Rimmer, M. (ed.) Intellectual Property and Clean Energy: The Paris Agreement and Climate Justice. Springer, Berlin. (In Press).

65 Steffen, W., Rockström, J., Richardson, K., Lenton, T.M. et al. (2018) Trajectories of the Earth System in the Anthropocene. Proceedings of the National Academy of Sciences USA https://doi.org/10.1073/pnas.1810141115

66 Palumbi,S.R., Barshis,D.J., Traylor-Knowles, N. and Bay, R.A. (2014) Mechanisms of reef coral resistance to future climate change. Science 344, 895-898.

67 Suchley, A., McField, M.D. and Alvarez-Filip, L. (2016), Rapidly increasing macroalgal cover not related to herbivorous fishes on Mesoamerican reefs.

PeerJ 4, e2084; DOI 10.7717/peerj.2084.

68 Johns, K.A., Emslie, M.J., Hoey, A.S., Osborne, K. et al. (2018) Macroalgal feedbacks and substrate properties maintain a coral reef regime shift. Ecosphere $\mathbf{9}$, Article e02349.

69 Baker, D.M., Freeman, C.J., Wong, J.C.Y., Fogel, M.L. and Knowlton, N. (2018) Climate change promotes parasitism in a coral symbiosis. The ISME Journal 12, 921-930 https://doi.org/10.1038/s41396-018-0046-8.

70 Merselis, D.G., Lirman, D. and Rodriguez-Lanetty, M. (2018) Symbiotic immunosuppression: is disease susceptibility the price of bleaching resistance? PeerJ $\mathbf{6}$, e4494; DOI 10.7717/peerj.4494.

71 Kavousi, J. and Keppel, G. (2017) Clarifying the concept of climate change refugia for coral reefs. ICES Journal of Marine Science 75, 43-49. doi:10.1093/icesjms/fsx124.

72 Birkeland, C., Green, A., Fenner, D., Squair, C. and A.L. Dahl, A.L. (2013) Substratum stability and coral reef resilience: insights from 90 years of disturbances on a reef in American Samoa. Micronesica 6, 1- 16.

73 Frölicher, T.L., Fischer, E.M. and Gruber, N. (2018) Marine heatwaves under global warming. Nature 560, 360-364.

74 Camp, E.F., Smith, D.J., Evenhuis, C., Enochs, I. et al. (2016) Acclimatization to high-variance habitats does not enhance physiological tolerance of two key 
Caribbean corals to future temperature and $\mathrm{pH}$. Proceedings of the Royal Society $B$ 283, 20160442. http://dx.doi.org/10.1098/rspb.2016.0442

75 Graham, N.A.J., Wilson, S.K., Carr, P., Hoey, A.S et al. (2018) Seabirds enhance coral reef productivity and functioning in the absence of invasive rats. Nature $559,250-253 . \mid$

76 Crabbe, M.J.C., Martinez, E., Garcia, C., Chub, J., Castro, L. and Guy, J. (2010) Is capacity building important in policy development for sustainability? A case study using action plans for sustainable Marine Protected Areas in Belize. Society and Natural Resources 23, 181-190.

77 Edgar, G.J., Stuart-Smith, R.D., Willis, T.J., Kininmonth, S., Baker, S.C. et al. (2014) Global conservation outcomes depend on marine protected areas with five key features. Nature 506, 216-220.

78 Curnick, D.J., Head, C., Huang, D., Crabbe, M.J.C. et al. (2015) Setting evolutionary-based conservation priorities for a phylogenetically data-poor taxonomic group (Scleractinia). Animal Conservation 18, 303-312. doi:10.1111/acv.12185.

79 Zheng, W., Wang, X., Tian, D., Jiang, S. et al. (2013) Water pollutant fingerprinting tracks recent industrial transfer from coastal to inland China. Scientific Reports 3, 1031. DOI:10.1038/srep01031.

80 Delevaux, J.M.S., Jupiter, S.D., Stamoulis, K.A., Bremer, L.L. and Wenger, A.S. (2018) Scenario planning with linked landsea models inform where forest conservation actions will promote coral reef resilience. Scientific Reports 8, 12465 DOI:10.1038/s41598-018-29951-0 1.

81 Downs, C.A., Kramarsky-Winter, E., Segal, R., Fauth, J. et al. (2016) Toxicopathological Effects of the Sunscreen UV Filter, Oxybenzone (Benzophenone3 ), on Coral Planulae and Cultured Primary Cells and Its Environmental Contamination in Hawaii and the U.S. Virgin Islands. Archives of Environmental Contamination and Toxicology 70, 265. https://doi.org/10.1007/s00244-015-0227-7.

82 Hankins, C., Duffy, A. and Drisco, K. (2018) Scleractinian coral microplastic ingestion: Potential calcification effects, size limits, and retention. Marine Pollution Bulletin 135, 587-593. https://doi.org/10.1016/j.marpolbul.2018.07.067

\section{Legends to Figures.}

Fig. 1. Economic benefits from ecosystem services for coral reef ecosystems.

Values are in US\$ / ha / year, on a logarithmic scale, and indicate the average value and the maximum value. Values from TEEB - The Economics of Ecosystems and Biodiversity for national and international policymakers - Summary: Responding to the value of nature, 2009 pp.47. Online at: www.wri.org. 
Fig.2. Identifying robust sources on the Great Barrier Reef. (A) Robust sources are the reefs that possess high replenishment potential while also having low risk of bleaching and COTS outbreaks. (B) When robust sources are superimposed on estimates of thermal stress, the region of lower stress in the southern GBR is visible. COTS,crown-of-thorns starfish; GBR, Great Barrier Reef; NCJ, North Caledonian Jet; SCJ, South Caledonian Jet. Modified from [16].

Fig.3. Meteorological processes influencing tropical marine life. Modified from [21].

Fig.4. Thermal stress and bleaching during the 2005 Caribbean bleaching event. (a) Maximum NOAA Coral Reef Watch Degree Heating Week values (DHW) showing the maximum thermal stress recorded at each pixel during 2005.

Values of $4{ }^{\circ} \mathrm{C}$-weeks typically results in significant bleaching; $8^{\circ} \mathrm{C}$-weeks typically results in widespread bleaching and mortality.

(b) Jurisdiction averages of bleached percent of live coral colonies (circles) and cover (diamonds). Modified from [27].

Fig.5. Overview of processes and proteins associated with gene expansions in $S$. pistillata and $A$. digitifera. (A) Gene Ontology (GO) enrichment of Biological Process (BP) category $(p<0.05)$ of many-to-one and many-to-many orthologs for $S$. pistillata and $A$. digitifera. Modified from [37].

Fig.6. Projected coral bleaching area under stratospheric aerosol geoengineering (left column) and RCP4.5 (right column) scenarios in 2030, 2050 and 2069, respectively. Modified from [59]. 